\title{
Manggis Menuju Kampung Jaranan
}

\author{
Aprinus Salam ${ }^{1}$, Wiwien Widyawati Rahayu ${ }^{2}$ \\ ${ }^{1}$ Program Studi Sastra Indonesia, Departemen Bahasa dan Sastra, FIB, UGM \\ ${ }^{2}$ Program Studi Sastra Jawa, Departemen Bahasa dan Sastra, FIB, UGM \\ Korespondesi: aprinus@ugm.ac.id
}

Tim Pengabdian kepada Masyarakat:

Anung Tedjowirawan, Rudi Ekasiswanto

\begin{abstract}
Many people are recently pushing their village to become a tourist village as best as they can. Manggis people has no exception; they also want their village to become a tourist destination. With their uniqueness, of course each village has the potential to become a tourist village. With its quite-high hill and rivers surrounding, its trademark art performances like tayub, sholawatan, and especially jaranan, the community service team of FIB UGM will be doing the best at empowering the local people and guiding them to establish Manggis village as a tourist village. The first thing to do is identifying the potentials that Manggis village owned and formulating those potentials to become tourist-worthy, afterward. However, with several limitations, mainly because the village is quite far from transportation centers and crowds, hence the most suitable tourism potential of Manggis village is as a special tourist village, namely to Kampung Jaranan.
\end{abstract}

Keywords: Manggis village, potential, tourist village, special tourism, Kampung Jaranan

\begin{abstract}
Abstrak
Saat ini, banyak masyarakat sedang memacu daerahnya untuk sebisa mungkin menjadi desa wisata. Tidak terkecuali masyarakat Manggis yang menginginkan desanya dapat menjadi salah satu destinasi wisata. Dengan keunikannya masing-masing, tentu setiap desa berpotensi untuk dijadikan desa wisata. Dengan potensi alam yang berbukit cukup tinggi dan bersungai sertaadanya kesenian khas seperti tayub dan sholawatan, terutama kampung jaranan, maka tim Pengabdian Masyarakat FIB UGM turut mengupayakan agar Desa Manggis dapat dijadikan desa wisata. Hal-hal yang dilakukan adalah dengan mengidentifikasi potensi yang dimiliki dan memformulasikan potensi itu menjadi layak wisata. Namun, dengan beberapa keterbatasan lainnya, utamanya karena desa ini cukup jauh dari pusat-pusat transportasi dan keramaian, maka potensi wisata Desa Manggis yang paling cocok adalah sebagai desa wisata khusus, yaitu Desa Manggis menuju Kampung Jaranan.
\end{abstract}

Kata Kunci: Desa Manggis, potensi, desa wisata, wisata khusus, Kampung Jaranan

\section{Pendahuluan}

Seperti telah menjadi pengetahuan bersama, Indonesia masih berupaya untuk menjadikan wilayahnya sebagai salah satu target wisata masyarakat internasional dengan keragaman potensi alam dan budaya yang layak saksi. Hal ini berpengaruh pada masyarakat yang bergeliat terus-menerus mempersiapkan daerahnya agar menarik dan layak kunjung 
wisata dengan potensi yang dimiliki. Hal yang sama juga terjadi bagi masyarakat Manggis, sebuah desa di Kecamatan Panggul, Kabupaten Trenggalek.

Persoalannya adalah apakah semua desa layak dijadikan destinasi wisata. Ini pula sebetulnya menjadi tantangan dalam melihat potensi Desa Manggis tersebut. Selain itu, Desa Manggis cukup jauh dari pusat transportasi seperti stasiun, terminal, apalagi bandara. Memang, persoalan jauh atau dekat tersebut sangat relatif dari mana posisi dan cara melihat Desa Manggis tersebut. Itulah sebabnya, perlu dicermati di mana posisi Desa Manggis tersebut seperti pada Ilustrasi 1 .

Desa Manggis terletak di Kecamatan Panggul, Kabupaten Trenggalek, Jawa Timur. Desa Manggis berjarak sekitar 8,2

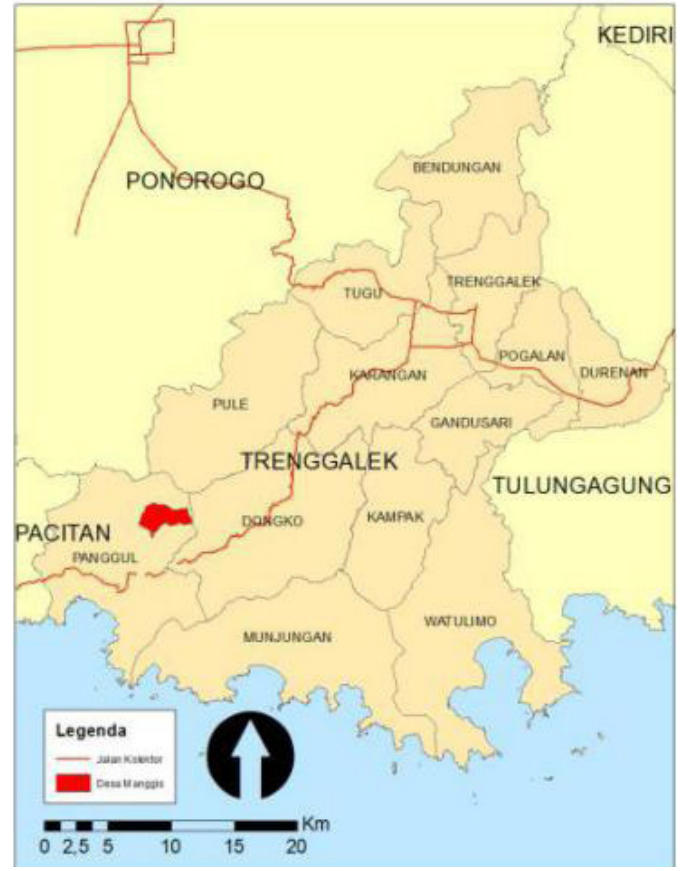

Ilustrasi 1. Peta Desa Manggis $\mathrm{km}$ dari pusat Kecamatan Panggul dan sekitar 53 km dari pusat Kota Trenggalek, Jawa Timur. Dari Kota Trenggalek, jarak yang ditempuh untuk menuju kota tersebut lebih kurang dua setengah jam.

Berangkat dari latar belakang tersebut, ada dua masalah yang akan coba dikaji dan dievaluasi terkait dengan kemungkinan bagaimana melihat peluang potensi Desa Manggis dapat dijadikan desa wisata.

1. Apa saja potensi Desa Manggis yang dapat dijadikan objek daya tarik wisata.

2. Bagaimana susunan hasil identifikasi potensi budaya (sebagai daya tarik wisata dalam bentuk program-program wisata khusus).

\section{Tujuan Kegiatan}

Berdasarkan dua masalah yang diuraikan sebelumnya, kegiatan pengabdian kepada masyarakat di Desa Manggis memiliki tujuan berikut.

1. Mengidentifikasi dan menyusun peta potensi wisata Desa Manggis.

2. Menyusun hasil identifikasi potensi budaya (sebagai daya tarik wisata dalam bentuk program wisata khusus).

\section{Konsep Pariwisata Budaya}

Sillberberg dalam Damanik (2013: 118) mendefinisikan pariwisata budaya sebagai kunjungan orang dari luar destinasi yang didorong oleh ketertarikan pada objekobjek atau peninggalan sejarah, seni, ilmu pengetahuan, dan gaya hidup yang dmiliki oleh kelompok, masyarakat, daerah, ataupun lembaga. Kristiningrum (2014: 47) mendefinisikan pariwisata budaya sebagai wisata yang di dalamnya terdapat aspek/ nilai budaya mengenai adat istiadat masyarakat, tradisi keagamaan, dan warisan budaya di suatu daerah. 
Pariwisata budaya berhubungan erat dengan daya tarik wisata budaya. Penjelasan Rencana Induk Pembangunan Kepariwisataan Nasional (RIPPARNAS) pasal 14 ayat (1) huruf $\mathrm{b}$ menjelaskan daya tarik wisata budaya adalah daya tarik wisata berupa olah cipta, rasa, dan karsa manusia sebagai makhluk budaya. Daya tarik wisata budaya dibedakan menjadi dua, yaitu daya tarik wisata budaya yang bersifat berwujud (tangible) dan daya tarik wisata budaya yang bersifat tidak berwujud (intangible).

\section{Pengembangan Destinasi Pariwisata}

Menurut UU nomor 10 tahun 2009 tentang kepariwisataan, daerah tujuan wisata yang selanjutnya disebut destinasi pariwisata adalah kawasan geografis yang spesifik berada dalam satu atau lebih wilayah administratif yang di dalamnya terdapat kegiatan kepariwisataan dan dilengkapi dengan ketersediaan daya tarik wisata, fasilitas umum, fasilitas pariwisata, aksesibilitas, serta masyarakat yang saling terkait. Hal itu, menurut Cooper dkk. dalam Sunaryo (2013: 159) dijelaskan sebagai komponen-komponen utama kerangka pengembangan destinasi pariwisata yang meliputi: (1) objek daya tarik wisata (attraction) yang mencakup keunikan dan daya tarik berbasis baik alam, budaya, maupun buatan/artificial; (2) aksesibilitas (accessibility) yang mencakup kemudahan sarana dan sistem transportasi; (3) amenitas (amenities) yang mencakup fasilitas penunjang dan pendukung wisata; (4) fasilitas umum (ancillary service) yang mendukung kegiatan pariwisata; (5) kelembagaan (institutions) yang memiliki kewenangan, tanggung jawab dan peran dalam mendukung terlaksananya kegiatan pariwisata.

\section{Praktik Pelaksanaan sebagai Metode}

1. Mengenali dan melakukan survei terhadap Desa Manggis dalam rangka melihat kemungkinannya sebagai desa wisata.

2. Melakukan pendekatan, dialog, dan sosialisasi apa yang diinginkan oleh masyarakat.

3. Mengidentifikasi dan memformulasikan potensi-potensi wisata.

4. Mencatat kendala dan keterbatasan.

5. Mendiskusikan hasil identifikasi dan formulasi bersama masyarakat.

6. Memberi petunjuk dan mengarahkan kesiapan (dan persiapan) masyarakat berdasarkan hasil riset potensi, aspirasi masyarakat, dan jenis wisata yang akan dikelola.

7. Memformulasikan wisata khusus dengan beberapa model.

8. Uji coba salah satu paket wisata khusus.

9. Evaluasi uji coba paket wisata khusus.

10. Memformulasikan rencana wisata khusus dengan model tertentu.

11. Membantu sosialisasi dan promosi ke publik yang lebih luas.

\section{Jalan Panjang Desa Manggis Menuju Destinasi Wisata Budaya}

Upaya menjadikan Desa Manggis menuju destinasi wisata salah satunya ditandai dengan adanya perhatian pemerintah daerah dengan alokasi anggaran khusus melalui dana desa serta upaya pendampingan yang dilakukannya. Dalam praktiknya, disadari penuh bahwa 
tanpa melibatkan unsur mitra dalam hal ini perguruan tinggi, apa yang digagasnya akan melalui jalan yang cukup panjang dan terjal. Hal ini diakui oleh Wakil Bupati pada saat memberikan arahan dan evaluasi kerja kemitraan antara Pemerintah Kabupaten Trenggalek dan DPkM UGM, di acara yang digagas Direktorat Pengabdian kepada Masyarakat UGM di University Club, Yogyakarta, beberapa waktu yang lalu. Semangat yang tumbuh, dengan membawa empati masyarakat akademis untuk hadir langsung di tengah-tengah masyarakat Manggis sangat memberikan dampak yang signifikan dengan hasil yang diharapkan. Karenanya, sungguh disayangkan apabila rintisan yang telah diawali dengan baik tidak ditindaklanjuti dengan sungguh-sungguh.

Dalam rangka menjawab tantangan tersebut, tim bentukan yang sudah ada sebelumnya, dengan pola pemberdayaan melalui skema KKN PPM, dikembangkan menjadi Tim Pengabdian kepada Masyarakat (PkM) FIB UGM. Pola, desain, skenario pemberdayaan masyarakat yang kami bangun dalam upaya bersama-sama memberdayakan masyarakat Desa Manggis, kami coba gambarkan sebagai berikut.

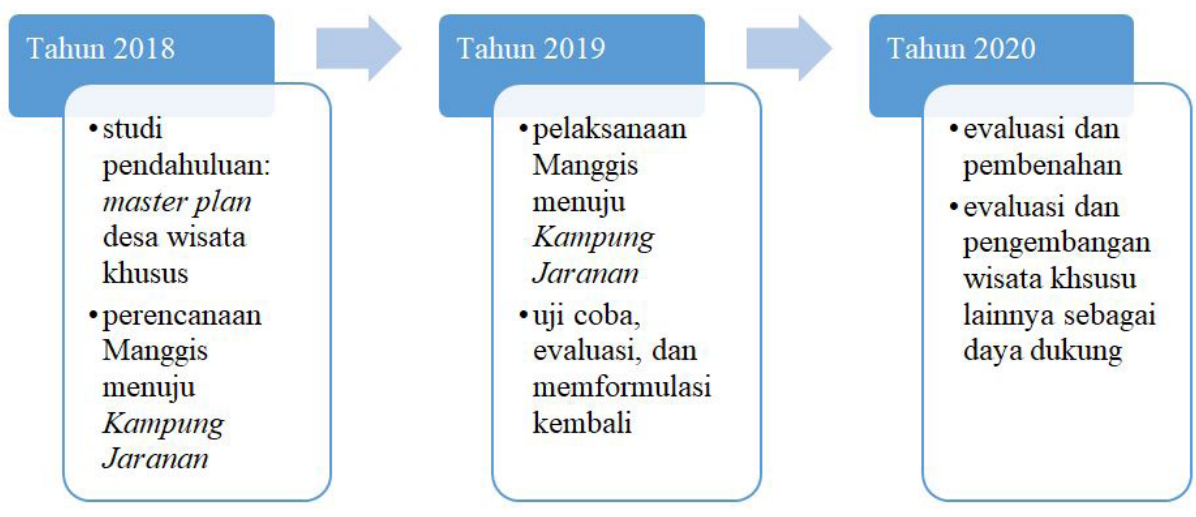

Ilustrasi 2. Skenario Pemberdayaan terhadap Masyarakat Desa Manggis

Tahapan berikutnya dalam upaya menguji potensi Desa Manggis tersebut yaitu standar umum kelayakan wisata dimanfaatkan.Hal ini dikarenakan bahwa suatu tempat baru bisa menjadi sebuah destinasi wisata, apabila terdapat atraksi (attraction), yaitu sesuatu yang bisa dilihat, dilakukan, bahkan dibeli. Terkait hal itu, potensi yang dapat diidentifikasi dideskripsikan sebagai berikut.

\section{Potensi Alam}

Desa Manggis adalah sebuah desa dataran tinggi yang terletak di bagian ujung Barat Daya wilayah Kabupaten Trenggalek. Desa ini berada di ketinggian 40-800 meter dpl dan memiliki sunga. Topografi desa ini berbukit-bukit sehingga persawahan dan ladang sebagai lahan utama penghidupan penduduk harus dibuat bertingkat. Terasering sawah dan ladang berfungsi sebagai pengatur irigasi persawahan ataupun penahan longsor pada ladang. Terasering ini merupakan cermin dari bertahannya budaya lokal, khususnya bertahannya sistem mata pencaharian di bidang pertanian.

Kondisi alam Desa Manggis yang masih asri, bukit-bukit, aliran sungai dan persawahan menjadi daya tarik utama desa ini. Selain itu, juga keindahan sumber daya 


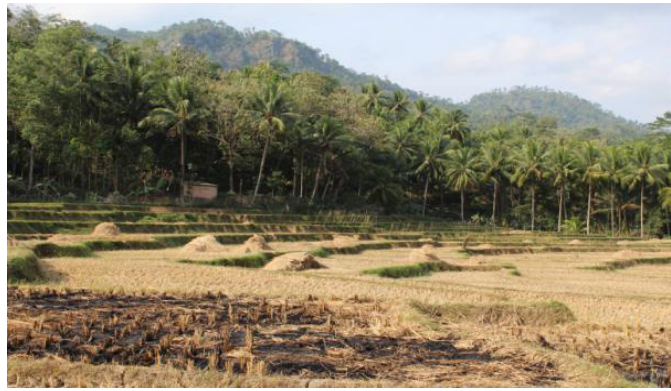

Ilustrasi 3. Terasering sawah di Desa Krajan

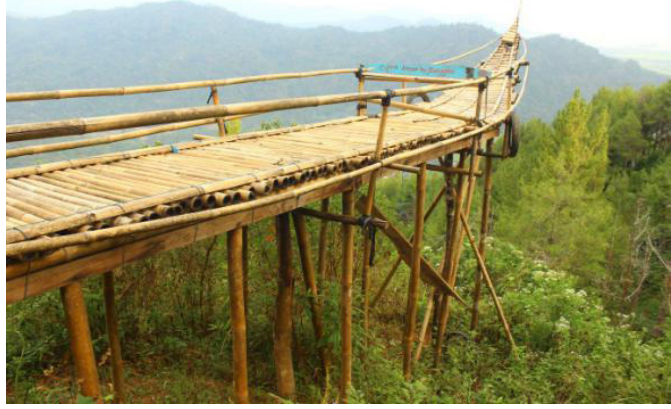

Ilustrasi 5. Gardu pandang di Dusun Pager Watu (Dusun Petung)

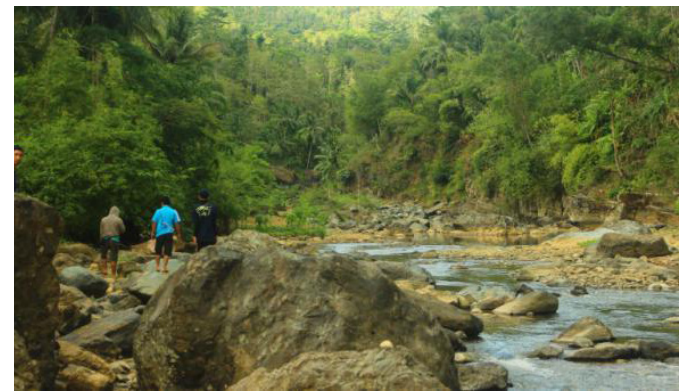

Ilustrasi 4. Sungai yang mengalir di sepanjang Desa Manggis

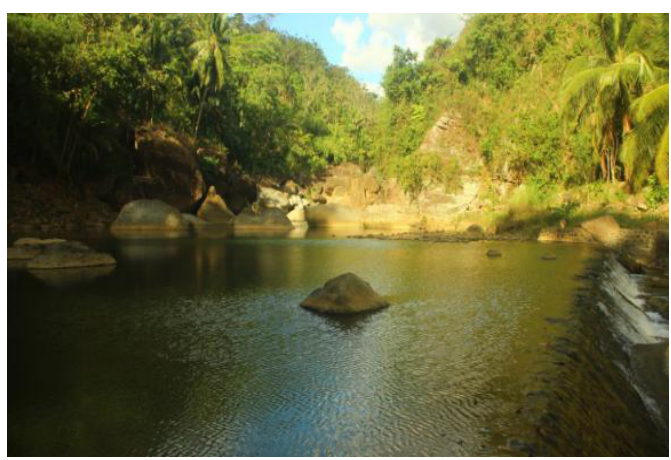

Ilustrasi 6. Dung Dinding

alam seperti bukit Taman Senggani, wisata alam Dung Dinding, Sungai Manggis, Bukit Pagerwatu yang berpotensi untuk dijadikan atraksi wisata-alam.

Berikutnya, adapun mina padi yang merupakan aktivitas menanam padi secara tradisional dengan memanfaatkan genangan air sawah yang ditanami padi menjadi kolam budidaya ikan. Dengan demikian, hal ini akan meningkatkan efisiensi lahan karena dalam suatu waktu digunakan untuk sarana dua komoditas pertanian. Pada kegiatan mina padi, potensi yang diharapkan sebagai pendukung wisatawan, yaitu diberikannya materi mengenai mina padi, mempraktikkan cara membuat bengkeng (alat penangkap ikan tradisional) sekaligus mempraktikkan cara penggunaannya. Ikan hasil tangkapan tersebut, nantinya dapat diolah dan dimakan bersama-sama di homestay.

\section{Potensi Budaya}

Berikut beberapa potensi penting Desa Manggis yang layak dipertimbangkan sebagai pendukung desa utamanya sebagai desa wisata.

\section{Jaranan Turonggo Yakso Komunitas Seni Argo Budoyo}

Jaranan merupakan seni pertunjukan yang digemari oleh masyarakat luas dari mulai muda sampai tua. Namun, seiring berjalannya waktu dengan perkembangan zaman yang semakin modern, jaranan pun ikut menyesuaikan dengan mengkombinasikan tarian dengan musik yang modern. Hal tersebut bertujuan agar lebih menarik perhatian masyarakat, terutama generasi muda. 


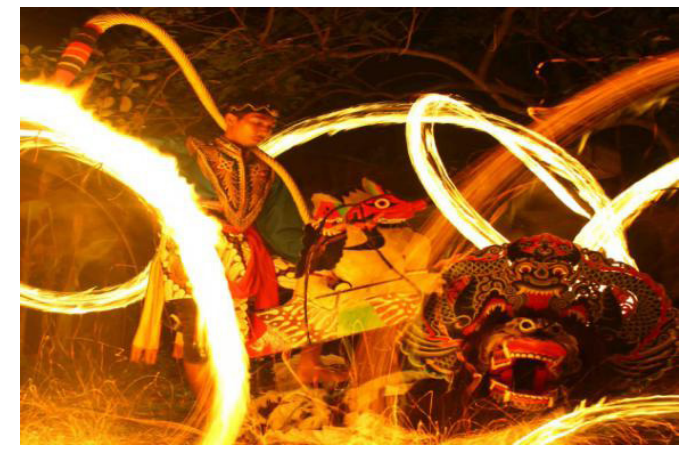

Ilustrasi 6. Aksi Jaranan Turonggo

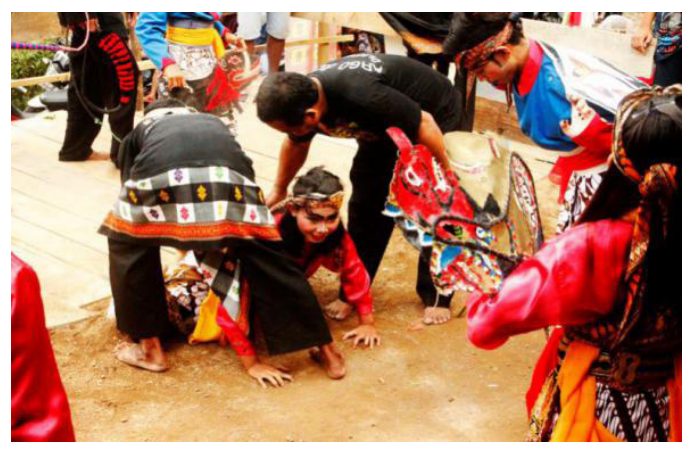

Ilustrasi 7. Jaranan Turonggo ndadi

Argo Budoyo merupakan suatu komunitas seni yang berada di RT 02 Dukuh Manggis, Dusun Krajan, Desa Manggis. Argo memiliki arti 'gunung', sedangkan budoyo merupakan kebudayaan itu sendiri, sehingga secara keseluruhan Argo Budoyo berarti kesenian yang ada di gunung karena sejatinya Desa Manggis berada di daerah pegunungan. Komunitas ini didirikan oleh Bapak Sardi dan kawan-kawan, salah seorang tokoh kesenian di Desa Manggis.

Komunitas Argo Budoyo sampai saat ini telah berjalan kurang lebih selama lima tahun. Namun, pada perjalanannya komunitas ini sempat berhenti selama dua tahun. Sekarang, komunitas ini dipimpin Bapak Eko. Jumlah anggota berkisar 50-60 orang, terdiri dari dewasa, remaja dan anak-anak yang berasal dari dalam dan luar Desa Manggis. Komponen dari anggota Argo Budoyo ini sendiri terdiri dari lenggeran, celengan, penabuh, barongan, waranggono (sinden). Ciri khas yang ditampilkan dari komunitas jaranan Argo Budoyo ini adalah di tiap awal pertunjukan, diawali dengan memainkan dan menyanyikan tembang atau lagu Argo Budoyo yang diciptakan oleh Bapak Meslani, salah satu anggota Argo Budoyo.

Sepengetahuan kita bersama, bahwa dalam pertunjukan jaranan, terdapat suatu peristiwa puncak, yang ditandai dengan adanya pemain jaranan atau bahkan penonton kerasukan atau dalam istilah Jawa adalah ndadi. Ketika mereka ndadi mereka akan terus menari dengan lincah dan itu menjadi daya tarik tersendiri bahkan utama bagi penonton. Antara ingin tahu dan takut, menjadi sensasi tersendiri dan hal ini merupakan kekhasan, keunikan yang nantinya menjadi point of interest peluang destinasi wisata.

Komunitas ini biasanya tampil di acara peringatan hari besar Nasional, hajatan warga, ambal warsa komunitas, peresmian gedung, dan lain-lain.

\section{Sholawatan}

Sholawatan merupakan salah satu kebudayaan tradisional Jawa yang berkembang di Desa Manggis, Kecamatan Panggul, Kabupaten Trenggalek. Sholawatan berasal dari bahasa Arab 'sholawat'. Yang membedakan sholawatan Desa Manggis dengan desa lainnya adalah jumlah pemain yang hanya tujuh orang berusia lanjut dan adanya sesaji sesuai hajat orang yang mengundang. Hal ini menunjukkan kuatnya tradisi Jawa di Desa Manggis. Sumber bacaan berupa naskah Jawa pegon (huruf Hijaiyah berbahasa Jawa) yang kandungan isinya nilai-nilai berkaitan hubungan antara pencipta dan ciptaan-Nya. 


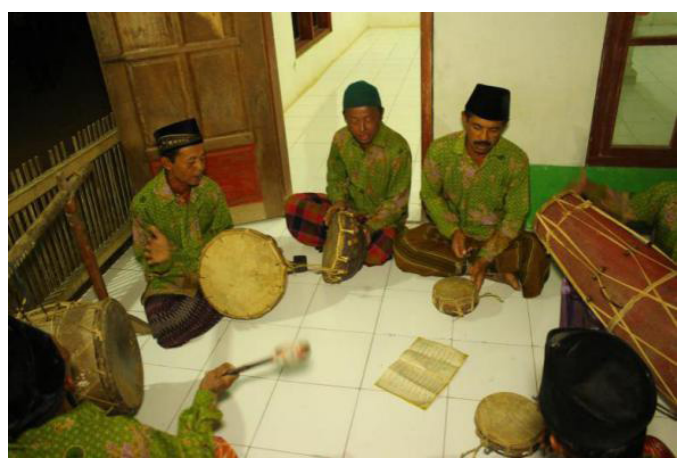

Ilustrasi 8. Kegiatan sholawatan Desa Manggis

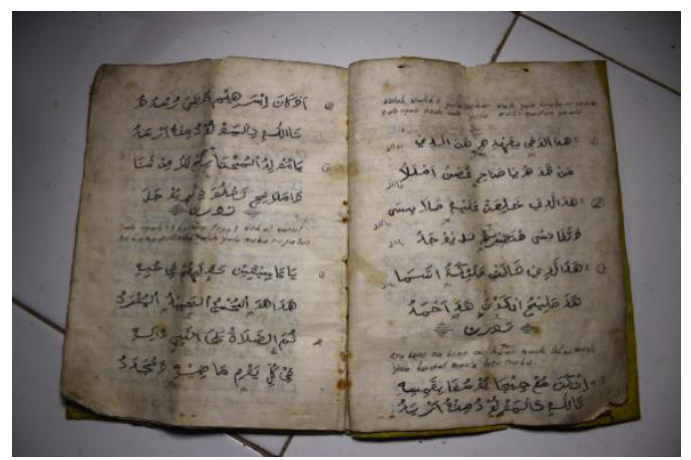

Ilustrasi 9. Salah satu contoh naskah sholawatan Desa Manggis

Menurut cerita dari Mbah Jamiran, penguri-uri sholawatan Desa Manggis bahwa tradisi sholawatan awal mulanya didirikan oleh Mbah Paidi yang berasal dari Ngrayun, Ponorogo. Secara rutin, Mbah Paidi mengajarkan sholawatan ke Desa Tangkil pada hari Senin dan Kamis. Latihan dilakukan secara rutin dan memerlukan kesabaran. Diakui oleh Mbah Jamiran niat dilakukan kegiatan ini pada waktu itu untuk pemecah kesunyian atau sepinya Desa Manggis, khususnya Dusun Petung. Meskipun asumsi kami, sholawatan merupakan salah satu metode penyebaran agama Islam. Untuk hal ini, diperlukan kajian tersendiri.

Seiring dengan berjalannya waktu, sholawatan dipercaya masyarakat setempat sebagai upacara adat yang pelaksanaannya berkembang dengan cara kolaborasi dengan upacara adat mitoni, khitanan, membayar nazar, ulang tahun ataupun hajat-hajat lainnya. Adapun sesaji dan doa yang dibacakan di tiap acara berbeda satu dengan lainnya. Sesaji yang ada, setiap benda yang digunakan, yang dijadikan sebagai pelengkap sesaji memiliki makna masing-masing yang berhubungan dengan nilai-nilai kemanusiaan dan ketuhanan.

Satu kelompok sholawatan hanya memiliki tiga naskah, yaitu satu adalah naskah asli yang diturunkan dari penulis pertama pada tahun 1977 dan dua yang lain adalah naskah salinan yang ditulis ulang oleh warga yang dianggap mampu oleh para pelaku tradisi sholawatan. Sayangnya, tradisi ini tidak berkembang. Hal ini mungkin terjadi karena eksklusivitas yang ditunjukkannya. Minimal tidak adanya upaya menerjemahkan atau memaknai bacaan yang ditembangkan sehingga pemahaman atasnya oleh generasi muda nyaris hilang.

\section{Kesenian Tayub}

Kesenian tayub merupakan salah satu kearifan lokal di Desa Manggis, Kecamatan Panggul, Kabupaten Trenggalek. Kata tayub merupakan singkatan dari "ditata supaya guyub". Tujuan tayub yaitu meringankan beban seseorang yang memiliki hajat. Selain itu, tayub digunakan untuk menarik perhatian penggemar tayub agar bersemangat datang ke acara hajatan. Mayoritas penggemar tayub ialah orang tua, meskipun tidak menutup kemungkinan remaja bahkan anak-anak.

Lagu-lagu yang digunakan di kesenian tayub biasa disebut gendingyang dilanggamkan dengan bahasa Jawa. Unsur utama dalam kesenian ini adalah pramugari, waranggono, 
dan pengrawit, dan unsur pendukungnya berbagai media elektronik seperti sound system, video shooting, dan radio.

Sebelum terorganisir seperti sekarang, kesenian ini masih bersifat individual. Kemudian pada tahun 1971, terbentuklah organisasi yang diprakarsai Pak Pojo dan Pak Sardi yang berprofesi sebagai pramugari tayub Desa Manggis. Lalu, pada tahun 2015, organisasi ini berkembang di tingkat Kecamatan Panggul, Kabupaten

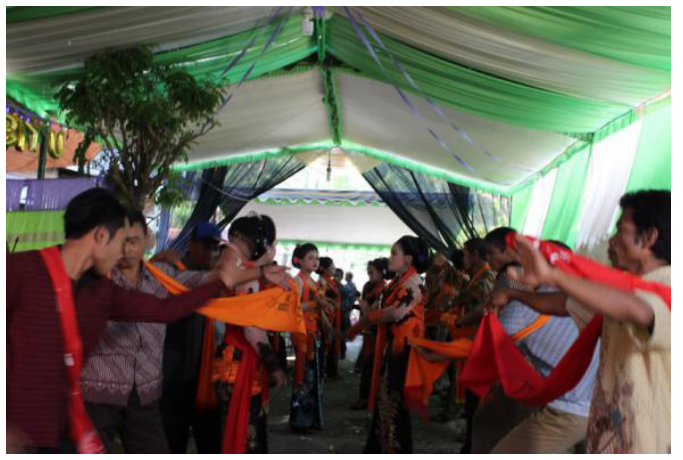

Ilustrasi 10. Tayub Desa Manggis Trenggalek. Tiap unsur dalam kesenian tayub dinaungi organisasi/komunitas/paguyuban, seperti pramugari dan waranggono sekecamatan Panggul dinaungi paguyuban "Margo Rukun". Pengrawit dinaungi paguyuban yang bernama "Rukun Budaya" berkedudukan di Desa Manggis

Pertunjukan tayub sebelum tahun 1971 dilaksanakan selama 24 jam. Namun, mulai tahun 1971, di Desa Manggis dilaksanakan mulai pukul 21.00-24.00 WIB dan dilanjutkan keesokan harinya, mulai pukul 09.00-17.00 WIB. Pakaian yang dikenakan penayub biasanya berseragam, kembaran dengan adat Jawa modifikasi atau biasa disebut modern (lawan dari klasik). Gamelan digunakan sebagai musik pengiring. Kesenian tayub hanya dipentaskan pada waktu-waktu tertentu (hari, wuku, bulan, tahu, dan windu) yang dipercaya baik/ bersih sesuai adat Jawa.

Standar umum kelayakan berikutnya adalah amenity, fasilitas pendukung kegiatan kepariwisataan seperti penginapan (hotel, losmen, guesthouse, homestay, atau rumah penduduk untuk live in). Selain itu, juga fasilitas lain seperti rumah makan, kios-kios suvenir, restoran, toilet, tempat sampah, dan lahan parkir sangat dibutuhkan untuk mendukung aktivitas kepariwisataan. Secara umum, meskipun fasilitas ini sudah ada, tetapi belum berkonsep.

Berikut sebagian produk dari masyarakat lokal Desa Manggis.

\section{Pengolahan Produk Lokal Menjadi Makanan dan Minuman}

Potensi alam berupa tanaman obat-obatan/rempah-rempah dan juga kelapa menonjol di Desa Manggis. Untuk itu, usaha skala rumah tangga banyak terdapat dan dikelola cukup baik, terbukti area pemasarannya sudah sampai lingkup kabupaten. Produk tersebut antara lain, pembuatan minuman jamu serbuk dari rempah-rempah, pembuatan makanan kecil: enting-enting jahe, roti kering/semprit kelapa, dan sebagainya.

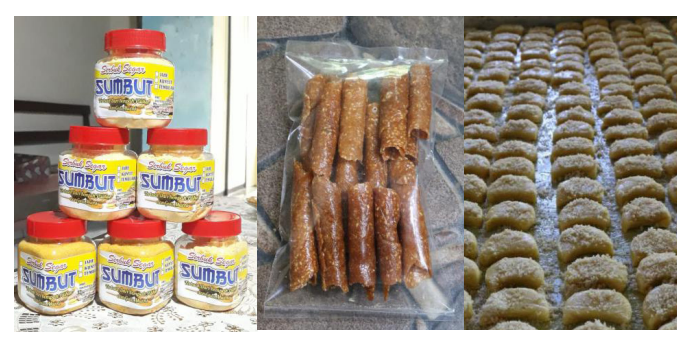

Ilustrasi 11. Jamu, enting-enting, dan roti semprit dari kelapa

\section{Pengolahan Minyak Atsiri}

Di Desa Manggis, ada beberapa masyarakat yang memiliki lahan cengkeh dan bahkan memiliki pabrik untuk penyulingan cengkeh menjadi minyak mentah. Hasil dari 
pengelolaan cengkeh tersebut merupakan salah satu yang mendukung kesejahteraan masyarakat Manggis karena harga jualnya yang mahal. Namun, hal tersebut terkendala karena adanya hama tanaman berupa lalat yang merusak pohon-pohon cengkeh tersebut.

Oleh karena itu, kegiatan pemberdayaan selanjutnya antara lain perlu adanya rencana tindak lanjut untuk mengatasi rusaknya pohon cengkeh tersebut. Selanjutnya, akan ada rencana pembuatan sentra penyulingan cengkeh yang akan berlokasi di Dusun Petung. Sentra penyulingan cengkeh tersebut akan dibuat menjadi wisata yang berbasis pembelajaran yang bermanfaat untuk memberikan informasi kepada para wisatawan tentang pengetahuan terkait keberadaan cengkeh di Indonesia, proses pembuatan cengkeh, manfaat dari cengkeh, dan hal-hal lain yang memungkinkan untuk dibagikan kepada para wisatawan.

Tempat sentra penyulingan nantinya tidak hanya sebagai rumah produksi, melainkan disediakan fasilitas untuk mendukung adanya edukasi cengkeh. Setelah itu, seluruh pemilik usaha penyulingan cengkeh akan bersatu di sentra dan juga terdapat pengurus yang akan mengurus sentra cengkeh seperti yang akan mengelola divisi produksi, divisi edukasi cengkeh, divisi keuangan, dan lain-lain.

\section{Dari Atraksi Sampai ke Prasarana}

Dengan potensi yang dimilikinya, terwujudnya Desa Manggis sebagai desa wisata dengan identitas budaya yang kuat bukan merupakan hal yang tidak mungkin. Akan tetapi, untuk saat ini hal tersebut masih terkendala beberapa persoalan, antara lain belum terpetakannya potensi-potensi wisata, belum adanya inventarisasi budaya yang memadai, kurangnya kesadaran akan pentingnya identitas budaya lokal, kurangnya regenerasi atas tradisi ataupun kesenian lokal yang ada sehingga terancam punah.

Dari segi atraksi budaya (peristiwa budaya), berbagai bentuk kesenian di Manggis belum bisa tampil secara reguler. Kesenian-kesenian tradisi tersebut hanya tampil pada hari-hari perayaan tertentu. Manajemen kesenian juga masih berjalan apa adanya, tidak tersistemkan dan tidak terprogram secara baik. Namun, jaranan Turongo dan sholawatan merupakan sesuatu yang khas. Walaupun kesenian ini terdapat di daerah lain, tetapi terdapat sesuatu yang unik di Manggis terutama pada musik pengiringnya dan gerakan-gerakan dalam aksinya.

Tidak dipungkiri, untuk mencapai atraksi diperlukan aksesibilitas yang meliputi infrastruktur dan keterjangkauan. Aspek infrastruktur dan keterjangkauan menjadi pertimbangan bagi masyarakat untuk berwisata.

Aspek ini terkait erat dengan sisi infrastruktur di sekitar obyek wisata, seperti fasilitas transportasi, bandara, angkutan masal, pelabuhan, termasuk rute penerbangan dan ketersediaan maskapai di sekitar objek wisata. Selain itu, kondisi jalan raya menuju lokasi obyek wisata bisa jadi akan menjadi salah satu pertimbangan. Infrastruktur lainnya adalah jaringan telekomunikasi.

Di samping itu, ancillary meliputi tata kelola destinasi obyek wisata. Tata kelola tersebut antara lain berupa pranata pengelola pariwisata, misalnya organisasi masyarakat atau pemerintah. Dalam konsep Pariwisata Berbasis Masyarakat, tata kelola melibatkan partisipasi aktif masyarakat setempat. Pranata lainnya berupa agen-agen perjalanan juga sangat berperan dalam mengembangkan suatu destinasi pariwisata. 


\section{Manggis Menuju Kampung Jaranan}

Berdasarkan penjelasan di atas, dapat diketahui bahwa Desa Manggis tidak cocok bila dijadikan desa wisata seperti pada umumnya. Sehubungan hal itu, dari hasil diskusi bersama masyarakat desa, tokoh masyarakat, yang dilaksanakan dalam berbagai forum termasuk juga dengan Pemda Kabupaten Trenggalek dan melalui Pengabdian kepada Masyarakat FIB UGM muncul tiga rancangan destinasi wisata khusus.

Hal ini sesuai dengan jumlah dusun yang ada, yaitu sebagai berikut.

Tabel 1. Rancangan dasar tiga paket wisata.

\begin{tabular}{|c|c|c|}
\hline $\begin{array}{c}\text { A. Paket Wisata Dusun } \\
\text { Krajan }\end{array}$ & $\begin{array}{c}\text { B. Paket Wisata Dusun } \\
\text { Pagerwatu }\end{array}$ & $\begin{array}{c}\text { C. Paket Wisata Dusun } \\
\text { Petung }\end{array}$ \\
\hline $\begin{array}{l}\text { Attraction } \\
\text { 1. Wisata budaya Turonggo } \\
\text { Yakso } \\
\text { 2. Mina padi } \\
\text { 3. Permainan di sungai } \\
\text { 4. Laminasi bambu } \\
\text { 5. Pembuatan minuman } \\
\text { tradisional } \\
\text { 6. Pembuatan keripik pisang }\end{array}$ & $\begin{array}{l}\text { Attraction } \\
\text { 1. Wisata edukasi } \\
\text { pembuatan minyak atsiri } \\
\text { 2. Wisata edukasi tempe } \\
\text { 3. Wisata alam }\end{array}$ & $\begin{array}{l}\text { Attraction } \\
\text { 1. Wisata alam } \\
\text { 2. Wisata edukasi } \\
\text { pembuatan minuman } \\
\text { tradisional } \\
\text { 3. Wisata edukasi } \\
\text { pembuatan minyak atsiri }\end{array}$ \\
\hline $\begin{array}{l}\text { Amenity } \\
\text { 1. Tempat menginap yang } \\
\text { layak } \\
\text { 2. Transportasi selama di } \\
\text { lokasi } \\
\text { 3. Makanan dan minuman } \\
\text { lokal }\end{array}$ & $\begin{array}{l}\text { Amenity } \\
\text { 1. Tempat menginap yang } \\
\text { layak } \\
\text { 2. Transportasi selama di } \\
\text { lokasi } \\
\text { 3. Makanan dan minuman } \\
\text { lokal } \\
\end{array}$ & $\begin{array}{l}\text { Amenity } \\
\text { 1. Tempat menginap yang } \\
\text { layak } \\
\text { 2. Transportasi selama di } \\
\text { lokasi } \\
\text { 3. Makanan dan minuman } \\
\text { lokal }\end{array}$ \\
\hline $\begin{array}{l}\text { Ancillary } \\
\text { 1. Pemandu/pendamping } \\
\text { yang mumpuni } \\
\text { 2. Jasa antar jemput sesuai } \\
\text { kesepakatan } \\
\text { 3. Host family } \\
\text { 4. Masyarakat yang ramah }\end{array}$ & $\begin{array}{l}\text { Ancillary } \\
\text { 1. Pemandu/pendamping } \\
\text { yang mumpuni } \\
\text { 2. Jasa antar jemput sesuai } \\
\text { kesepakatan } \\
\text { 3. Host family } \\
\text { 4. Masyarakat yang ramah }\end{array}$ & $\begin{array}{l}\text { Ancillary } \\
\text { 1. Pemandu/pendamping } \\
\text { yang mumpuni } \\
\text { 2. Jasa antar jemput sesuai } \\
\text { kesepakatan } \\
\text { 3. Host family } \\
\text { 4. Masyarakat yang ramah }\end{array}$ \\
\hline
\end{tabular}

Selanjutnya, tiga rancangan ini menjadi dasar kajian yang lebih mendalam untuk memilih paket wisata mana yang akan menjadi prioritas garapan. Selanjutnya, dipilihlah Paket Wisata A yang terletak di Dusun Krajan dengan alasan sebagai berikut.

1. Unsur keunikan yang menjadi daya tarik ada di kesenian jaranan

2. Adanya daya dukung masyarakat yang lahir, tumbuh, dan berkembang sebagai masyarakat jaranan.

3. Kesiapan masyarakat dusun dalam upaya menuju desa destinasi wisata.

4. Minimnya konflik internal.

Keempat alasan ini sementara dianggap cukup untuk mendisain prioritas tindakan terhadap Dusun Krajan dalam rangka Manggis menuju Kampung Jaranan. 


\section{Langkah 1}

Menyusun sebuah peta (pendahuluan) untuk melihat kedudukan Dusun Krajan di lingkup Desa Manggis. Dengan peta ini diharapkan upaya aksesibilitas secara awal dapat dilihat dan diketahui. Lihat Ilustrasi 12.

Selanjutnya, dari peta administrasi tersebut dikembangkan lebih lanjut menjadi peta yang sudah spesifik menunjuk pada Paket Wisata A di Dusun Krajan yang selanjutnya disebut 'Manggis Menuju Kampung Jaranan', dengan kedudukan fasilitas yang merupakan standar umum kelayakan sebagai destinasi wisata, seperti pada Ilustrasi 13.

\section{Langkab 2}

Menyusun naskah yang menjadi dasar dalam rangka mewujudkan 'Manggis Menuju Kampung Jaranan' dengan pertimbangan sebagai berikut.

Masyarakat Desa Manggis sebagian besar bermata pencaharian sebagai petani. Di sela-sela waktu mereka bekerja biasanya mereka melakukan aktivitas yang dapat menambah penghasilan. Adapun kegiatan yang dilakukan adalah dengan mengadakan pertunjukan jaranan. Seni pertunjukan jaranan memberikan dampak terhadap berbagai pihak, dari bidang ekonomi, masyarakat hingga pemerintahan. Kampung Jaranan merupakan suatu tempat yang akan memberikan atraksi dan edukasi wisata mengenai kebudayaan seni pertunjukan jaranan.

Jaranan merupakan seni pertunjukan yang digemari oleh masyarakat luas dari mulai muda sampai tua. Namun, seiring berjalannya waktu dengan perkembangan zaman yang semakin modern, Jaranan pun ikut menyesuaikan dengan mengkombinasikan tarian dengan musik yang modern atas permintaan masyarakat. Hal tersebut agar masyarakat terutama generasi muda tidak cepat bosan.

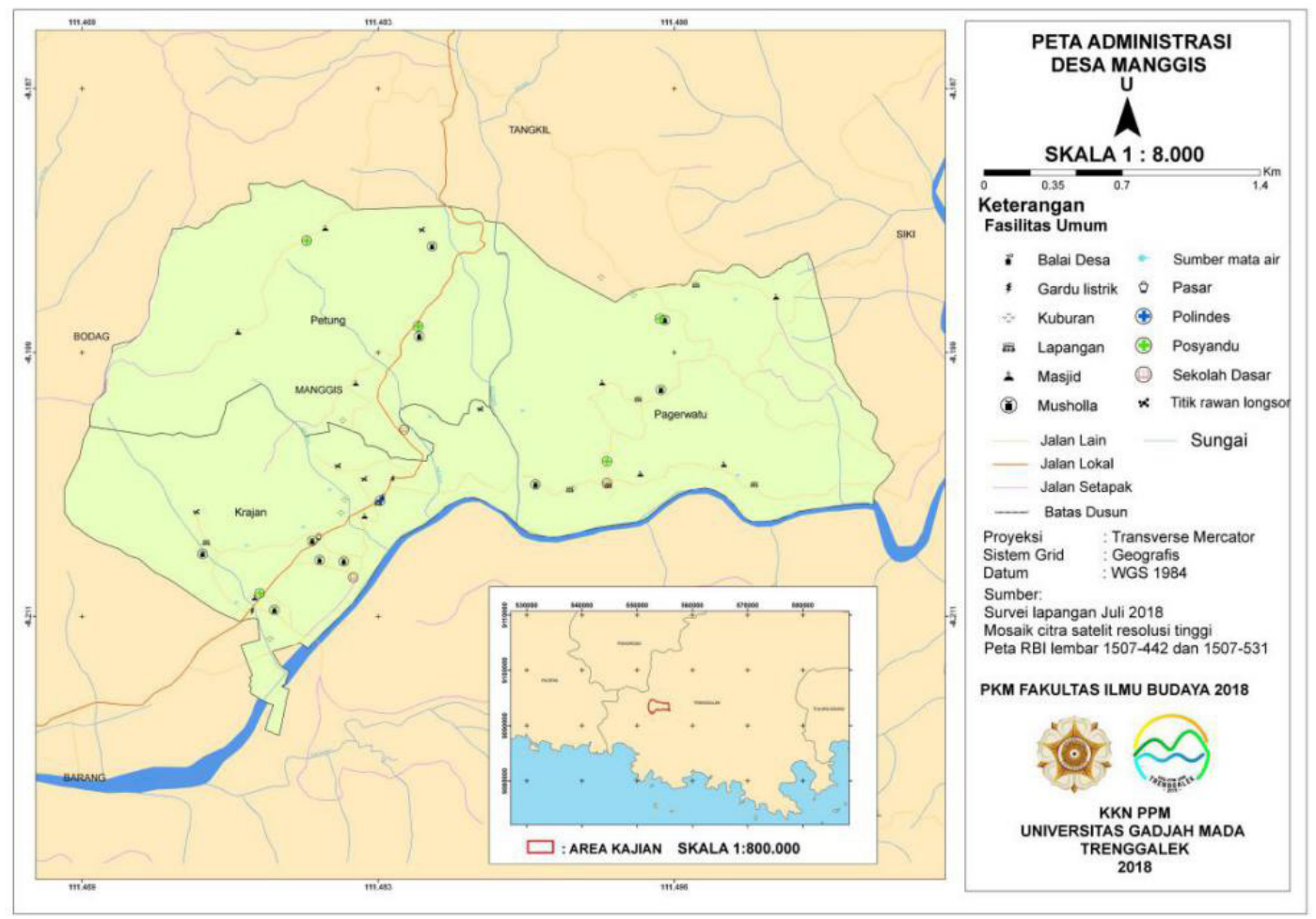

Ilustrasi 12. Peta administrasi Dusun Krajan di Desa Manggis 


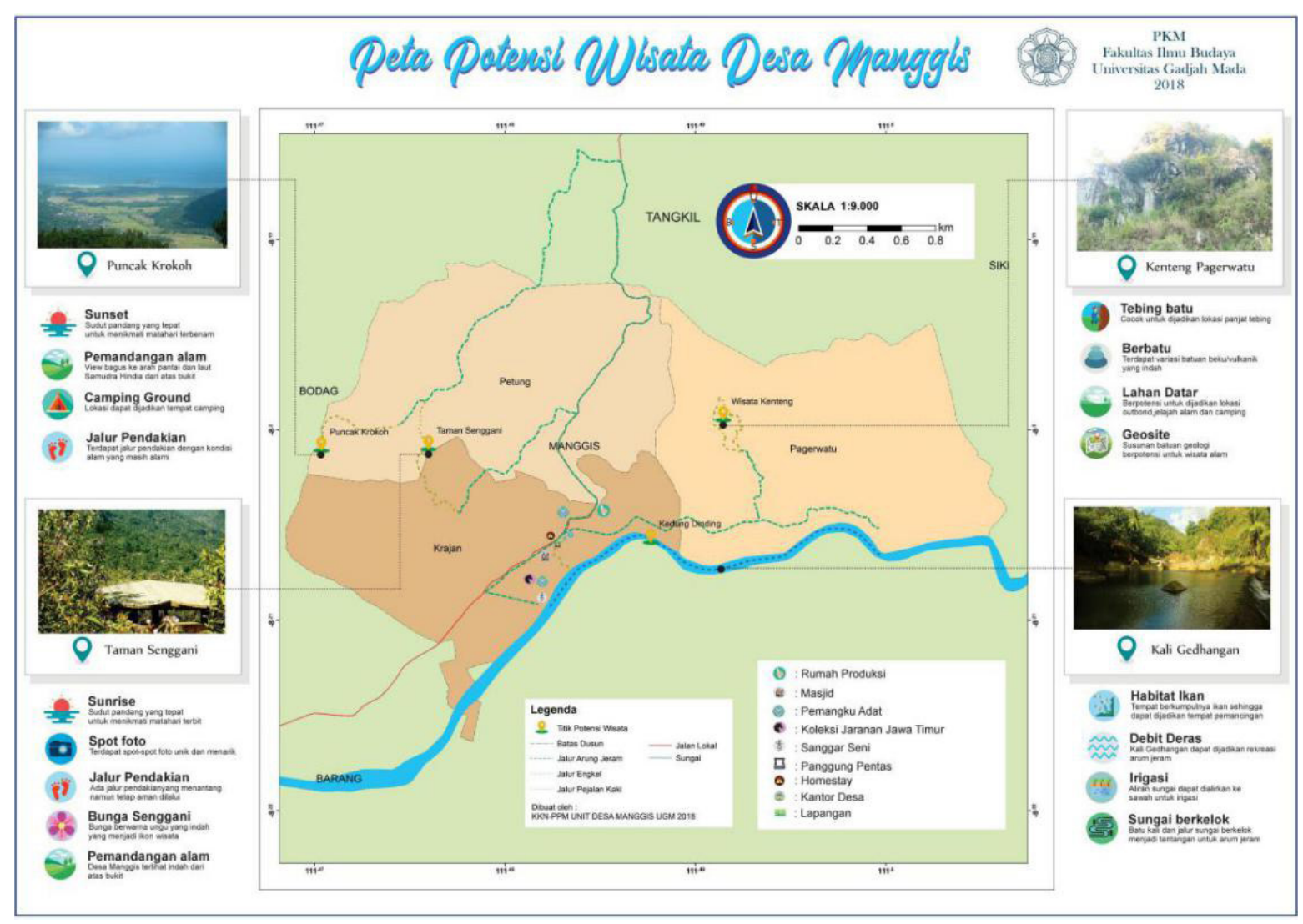

Ilustrasi 13. Peta Manggis menuju Kampung Jaranan

Pertunjukan jaranan sebagai salah satu kesenian daerah memiliki beberapa fungsi. Pertama, pertunjukan jaranan sebagai sarana ritual. Hal tersebut dapat dilihat pada pertunjukan jaranan dalam upacara bersih desa dan peringatan tentang siklus kehidupan (kelahiran, khitanan, pernikahan). Dalam acara bersih desa, pertunjukan jaranan tampil sebagai simbol energi positif desa yang akan memerangi dan menjaga desa dari hal-hal yang berbahaya. Jaranan juga sebagai simbol pemersatu masyarakat baik masyarakat sebagai penonton maupun pelaku seninya (guyub rukun). Kedua, pertunjukan jaranan sebagai ungkapan ekspresi pribadi. Hal tersebut dapat dilihat dai pelaku seni yang menjadi suatu kebanggaan dan kehormatan bagi masyarakat yang tampil dalam pertunjukan Jaranan. Mereka dapat mengekspresikan diri melalui karya seni yang dapat dinikmati oleh masyarakat luas. Ketiga, pertunjukan jaranan berfungsi sebagai hiburan, hal tersebut dapat dilihat dari penonton yang melihat pertunjukan. Keempat, pertunjukan jaranan memiliki fungsi estetis. Hal tersebut dapat dilihat pada penataan gerak, pola lantai, busana, rias tari, iringan musik dan ekspresi penarinya. Kelima, pertunjukan jaranan memiliki fungsi melestarikan kebudayaan tradisional yang dimunculkan oleh komunitas pelaku kesenian pertunjukan jaranan.

Pertunjukan tradisional jaranan tersebar hampir di seluruh daerah yang ada di Jawa Timur. Dari identifikasi penelitian ditemukan 34 kabupaten/kota memiliki kesenian jaranan dan 4 kabupaten/kota belum teridentifikasi kesenian jaranannya. Bentuk dan fungsi pertunjukan jaranan memiliki persamaan dan perbedaan. 
Rancangan layanan yang akan diberikan di Kampung Jaranan yaitu sebagai berikut.

\begin{tabular}{|c|c|}
\hline \multicolumn{2}{|r|}{ Attraction } \\
\hline $\begin{array}{l}\text { Mengenal } \\
\text { sejarah } \\
\text { jaranan }\end{array}$ & $\begin{array}{l}\text { Pada sesi ini wisatawan akan mendapatkan materi mengenai sejarah kesenian } \\
\text { pertunjukan jaranan secara umum dan sejarah berdirinya pertunjukan jaranan } \\
\text { Argo Budoyo yang ada di Desa Manggis secara khusus. Materi tersebut } \\
\text { akan disampaikan oleh pemangku adat atau pendiri kesenian pertunjukan } \\
\text { jaranan Argo Budoyo secara langsung. Pada sesi ini juga dijelaskan mengena } \\
\text { pandangan masyarakat mengenai adanya sesi "kerasukan" dalam sen } \\
\text { pertunjukan jaranan, tetapi hal tersebut hanya dilakukan oleh pemain penyaj } \\
\text { wisata yang sudah berpengalaman dan hanya sebagai atraksi yang tidak } \\
\text { disarankan bagi pengunjung. Pengunjung akan didampingi oleh pemandu } \\
\text { wisata untuk menemui narasumber di kampung jaranan. }\end{array}$ \\
\hline $\begin{array}{l}\text { Mengenal } \\
\text { jaranan lebih } \\
\text { dekat }\end{array}$ & $\begin{array}{l}\text { Pertunjukan Jaranan memiliki beberapa unsur pementasan, seperti tari/gerak, } \\
\text { kostum, musik pengiring, pola lantai, dan penari. Sebelum mendapatkan } \\
\text { fasilitas belajar menari, wisatawan mendapatkan teori mengenai beberapa tar } \\
\text { yang ada sehingga wisatawan memiliki referensi jenis dan tingkat kesulitan } \\
\text { tarian. }\end{array}$ \\
\hline $\begin{array}{l}\text { Belajar musik } \\
\text { jaranan }\end{array}$ & $\begin{array}{l}\text { Gamelan merupakan alat musik sebagai pengiring utama dalam petunjukan } \\
\text { jaranan. Dalam sesi ini, wisatawan disajikan satu set gamelan dengan buku } \\
\text { referensi jenis alat musik yang menjadi unsur-unsur gamelan. Referens } \\
\text { tersebut dapat dijadikan sebagai landasan wisatawan memilih alat musik } \\
\text { mana yang akan dimainkan bersama pemandu. Jika wisatawan merupakan } \\
\text { kelompok pemain musik, maka akan ditawarkan untuk menjadi pemusik } \\
\text { dalam pementasan jaranan. Dengan demikian, kampung jaranan juga } \\
\text { dapat dijadikan sebagai wahan praktikum lapangan bagi instansi kesenian }\end{array}$ \\
\hline $\begin{array}{l}\text { Menari tari } \\
\text { jaranan }\end{array}$ & $\begin{array}{l}\text { Dalam pertunjukan jaranan, atraksi yang paling utama adalah gerak tar } \\
\text { yang umum ditarikan. }\end{array}$ \\
\hline $\begin{array}{l}\text { Praktik } \\
\text { jaranan }\end{array}$ & $\begin{array}{l}\text { Wisatawan diberi kesempatan untuk ikut dalam pementasan singkat, } \\
\text { penggalan dari rangkaian panjang pementasan jaranan. Kesempatan in } \\
\text { berfungsi untuk mempraktikkan pembelajaran yang didapat. Peran dipilih } \\
\text { sesuai permintaan wisatawan. }\end{array}$ \\
\hline $\begin{array}{l}\text { Museum } \\
\text { jaranan }\end{array}$ & Koleksi jaranan Jawa Timur menjadi prioritas di museum ini. \\
\hline \multicolumn{2}{|r|}{ Amenity } \\
\hline \multicolumn{2}{|r|}{$\begin{array}{l}\text { 1. Homestay } \\
\text { 2. Photobooth } \\
\text { 3. Sewa Kostum } \\
\text { umah Produksi Jaranan } \\
\text { 5. Area Terbuka } \\
\text { 6. Panggung Pentas } \\
\text { 7. Kawasan parkir } \\
\quad \text { Masjid }\end{array}$} \\
\hline \multicolumn{2}{|r|}{ Ancillary } \\
\hline & $\begin{array}{l}\text { 1. Pemandu/pendamping yang mumpuni } \\
\text { 2. Jasa antar jemput sesuai kesepakatan } \\
\text { 3. Host family } \\
\text { 4. Masyarakat yang ramah }\end{array}$ \\
\hline
\end{tabular}




\section{Penutup}

Niat menjadikan sebuah daerah (suatu lokasi tertentu) menjadi layak wisata bukan persoalan mudah. Hal ini dialami oleh Desa Manggis. Minat, niat, dan semangat masyarakatnya untuk menjadikan desanya menjadi desa wisata harus didukung oleh potensi-potensi yang ada dalam masyarakat tersebut. Berdasarkan kajian Tim Pengabdian kepada Masyarakat FIB UGM, wisata yang layak dikembangkan di Desa Manggis adalah wisata khusus dengan mengembangkan secara sistematis dan terprogram segala hal yang terkait dengan Kampung Jaranan. Hal yang unik dari KampungJaranan adalah hampir semua warga terlibat aktif dalam kegiatan prosesi, ritual, hingga hal-hal teknis (keterampilan) jaranan dan menjadi kegiatan sehari-hari mereka.

Dengan paket wisata khusus yang telah dirancang, para wisatawan diharapkan akan mendapatkan pengalaman baru dan aneh, meliputi pengalaman teknis njaran dengan seni tari atau musiknya yang khas, atau bahkan bisa saja para wisatawan tersebut belajar dan mengalami ndadi jika memang berkenan. Dapat dibayangkan jika prosesi pengalaman tersebut terjadi di sebuah desa yang sunyi dan alam yang asri, dengan makanan khas Trenggalek, sambil sekali dua terdengar sayup-sayup suara sholawatan atau musik tayub.

\section{Daftar Pustaka}

Damanik, Phil Janianton (2013). Pariwisata Indonesia: Antara Peluang dan Tantangan. Yogyakarta: Pustaka Pelajar.

Kristiningrum, Nur Dwi (2014). "Heritage Tourism dan Creative Tourism: Eksistensi Pasar Seni (Central Market) di Malaysia sebagai Salah Satu Pasar Bersejarah". Jurnal Hubungan Internasional. Tahun VII, No. 1 Januari - Juni 2014. (Diakses 30 Oktober 2018, pukul 23:44 WIB).

Peraturan Pemerintah Republik Indonesia Nomor 50 Tahun 2011 tentang Rencana Induk Pembangunan Kepariwisataan Nasional Tahun 2010-2025.

Sunaryo, Bambang (2013). Kebijakan Pembangunan Destinasi Pariwisata Konsep dan Aplikasinya di Indonesia. Yogyakarta: Gava Media.

Tim KKN PPM (2018). Laporan Pendahuluan: Perencanaan dan Pengembangan Kawasan Pariwisata (Master Plan, Wisata Khusus Desa Manggis, Kecamatan Panggul, TrenggalekJawa Timur). Tidak diterbitkan. 